\title{
KECAKAPAN MANAJEMEN KELAS GURU SEBAGAI UPAYA \\ PENYELESAIAN PROBLEMATIKA PEMBELAJARAN DIMASA PANDEMI \\ COVID 19
}

\author{
Deni Sutisna ${ }^{1}$, Dyah Indraswati ${ }^{2}$ \\ 1,2PGSD FKIP Universitas Mataram \\ 1denisutisna@unram.ac.id, 2dyahindraswati@unram.ac.id
}

\begin{abstract}
This study aims to examine the extent to which teacher classroom management skills are an effort to solve learning problems during the Covid-19 pandemic in primary schools. The object of this research is the 2nd grade elementary school students at SDN Sidamukti Pangalengan Bandung and their teachers. The method used is descriptive method. Data collection was carried out by observation and interview techniques. The interview focused on the classroom teacher because he was the one who knew more about the problems of implementing learning during the Covid-19 pandemic and the solution to it. The results showed that learning problems during the Covid-19 pandemic in grade 2 SDN Sidamukti Pangalengan Bandung were divided into 3 dimensions. The three dimensions include: 1). problems faced by teachers; 2). problems faced by students; and 3). Problems faced by parents of students. The form of classroom management carried out by the teacher includes three stages; 1). The preparation stage by adjusting learning tools from offline learning to online learning, especially adjusting learning program plans (RPP); 2) implementation stage. The learning technique carried out by the teacher includes personal guidance online, forming student groups based on student abilities, making visits to small groups that have been formed beforehand, small groups of students visited by the teacher, providing modules and assignments that are collected and evaluated once a week. With such a management model, learning during the Covid-19 pandemic was more effective than online learning that had been carried out previously.
\end{abstract}

Keywords: Online Learning, Class Management, Problems, and Learning

\section{ABSTRAK}

Penelitian ini bertujuan untuk mengkaji sejauh mana kecakapan manajemen kelas guru sebagai upaya penyelesaian problematika pembelajaran di masa pandemi Covid-19 di sekolah dasar. Objek penelitian ini adalah siswa SD kelas 2 pada SDN Sidamukti Pangalengan Bandung beserta gurunya. Metode yang digunakan adalah metode deskriptif. Pengumpulan data dilakukan dengan teknik observasi dan wawancara. wawancara terfokus kepada guru kelas karena beliau yang lebih mengetahui problematika pelaksanaan Pembelajaran di masa pandemi Covid-19 serta solusi penyelesaiannya. Hasil penelitian menunjukkan bahwa problematika Pembelajaran di masa pandemi Covid-19 pada kelas 2 SDN Sidamukti Pangalengan Bandung dibagi menjadi 3 dimensi. Ke tiga dimensi tersebut meliputi: 1). permasalahan yang dihadapi oleh guru; 2). permasalahan yang di hadapi siswa; 
dan 3). Permasalahan yang dihadapi oleh Orang tua siswa. Adapun bentuk manajemen kelas yang dilakukan oleh guru meliputi tiga tahapan; 1). Tahap persiapan dengan menyesuaikan perangkat pembelajaran dari pembelajaran luring ke pembelajaran daring terutama penyesuaian rencana program pembelajaran (RPP); 2) tahap pelaksanaan. Teknis pembelajaran yang dilakukan oleh guru termasuk bimbingan pribadi melalui daring, membentuk kelompok siswa berdasarkan kemampuan siswa, melakukan kunjungan kepada kelompok kecil yang telah dibentuk sebelumnya, kelompok kecil siswa yang dikunjungi guru, memberikan modul dan penugasan yang dikumpulkan dan di evaluasi setiap satu minggu sekali. Dengan model manajemen seperti itu pembelajaran di masa pandemi Covid-19 lebih efektif dibandingkan pembelajaran online yang telah di laksanakan sebelumnya.

Kata Kunci: Pembelajaran Daring, Manajemen Kelas, Problematika, dan pembelajaran

\section{A. Pendahuluan}

Tidak terasa pelaksanaan Pembelajaran di masa pandemi Covid-19 yang di keluarkan pemerintah sebagai respon penyebaran pandemi Covid-19 Di Indonesia telah berjalan hampir satu tahun. Meskipun menghadapi pro dan kontra, Pembelajaran di masa pandemi Covid-19 di tujukan agar siswa tetap mendapatkan hak belajarnya meskipun di tengah anjuran untuk tetap berdiam diri di rumah.

Sebagaimana kita ketahui Pembelajaran di masa pandemi Covid-19 di sini adalah pembelajaran daring. Ini adalah program yang baru. Idealnya sebuah program penelitian yang akan di terapkan harus melewati tahan pengujian dan penelitian agar kualitas program sudah teruji. Di kutip dari Waridah \& Suzana, (2014). pengujian merupakan percobaan untuk mengetahui mutu sesuatu. Selain itu Mustaqbal, Firdaus, \& Rahmadi, (2015) menjelaskan bahwa pengujian bertujuan untuk mencari sebuah kesalahan atau kekurangan sebuah program sehingga bisa menentukan formulasi yang baik untuk menyelesaikan permasalahan tersebut. Sementara itu program pembelajaran daring merupakan respons instan dari kementerian pendidikan dan kebudayaan agar siswa dapat bersekolah di masa pandemi seperti ini. Oleh karena itu pelaksanaan Pembelajaran di masa pandemi Covid-19 belum bisa optimal dilaksanakan dan masih menghadapi berbagai permasalahan baik teknis 
ataupun non teknis. Rigianti, (2020) mengatakan bahwa permasalahan tersebut timbul dari berbagai aspek baik dari instansi, guru, dan siswa

Permasalahan Pembelajaran di masa pandemi Covid-19 semakin dirasakan oleh guru yang mengajar di sekolah dasar terutama kelas rendah. Sebagai mana kita ketahui untuk kelas rendah di SD kemandirian belajar siswa belum terbentuk. Mengajar di kelas rendah memerlukan fokus yang lebih dibandingkan dengan kelas atas, oleh karena itu guru harus lebih gigih dalam menciptakan pembelajaran yang menarik agar lebih efektif, (Kawuryan, 1992). Telah banyak penelitian-penelitian yang mengkaji terkait permasalahan dan kendala pelaksanaan pembelajaran daring di sekolah Dasar. Seperti halnya penelitian dari (Anugrahana, 2020) yang menyatakan bahwa pembelajaran daring di sekolah dasar masih menghadapi kendala dalam implementasinya. Lebih lanjut kajian dari (Roni Hamdani \& Priatna, 2020) bahwa kendala pembelajaran daring pada sekolah dasar terletak pada pengadaan perangkat, biaya, kenyamanan belajar siswa, dan jaringan internet. Selain itu penelitian dari (Rahmawati, Rosida, \& Kholidin,
2020) yang menyatakan bahwa hambatan pembelajaran daring terletak bapa kurangnya motivasi dan minat belajar peserta didik, kondisi ekonomi, dan keterbatasan guru dalam memfasilitasi siswa belajar.

Di tengah permasalahan tersebut guru harus senantiasa berupaya agar tujuan pembelajaran harus tetap di capai. Oleh karena itu guru harus bisa membuat desain pembelajaran agar pembelajaran tetap optimal. Di sinilah kemampuan guru dalam manajemen kelas daring dibutuhkan agar pembelajaran bisa berjalan dengan efektif dan efisien.

Manajemen kelas merupakan bentuk upaya guru dalam mengelola dan mengemas pembelajaran agar pembelajaran terstruktur, sistematis menyenangkan sehingga dapat mengoptimalkan potensi peserta didik. Rusyan, Winarni, \& Hermawan, (2020) mengatakan bahwa manajemen kelas merupakan suatu proses perencanaan, pengorganisasian, dan pengaktualisasian serta pelaksanaan supervisi dan pengawasan terhadap kegiatan dan program yang ada di kelas. Tujuannya untuk meningkatkan efektifitas proses belajar mengajar 
sehingga tujuan pembelajaran bisa tercapai (Efendi \& Gustrinasi, 2020)

Penelitian ini bertujuan untuk mengkaji sejauh mana kemampuan guru dalam memaksimalkan manajemen kelas guna menyelesaikan permasalahanpermasalahan pelaksanaan pembelajaran daring sehingga Pembelajaran di masa pandemi Covid-19 bisa lebih efektif. Hal ini penting mengingat pendidikan merupakan satu-satu nya jalan dalam menentukan arah kemajuan hidup manusia. Oleh karena itu penelitian ini akan sangat bermanfaat manakala mampu menganalisis permasalahanpermasalahan yang tengah terjadi, dan bisa menemukan solusi tepat untuk permasalahan tersebut. Oleh karena itu pengkajian kemampuan manajemen guru yang telah diterapkan Oleh Guru Kelas 2 SDN Sidamukti pengalengan bandung diharapkan dapat memberikan suatu pandangan atau model manajemen kelas yang tepat sehingga dapat di kembangkan agar nilai manfaatnya bisa lebih luas.

\section{B. Metode Penelitian}

Penelitian ini mencoba mengkaji terkait dengan sejauh mana kecakapan manajemen kelas guru sebagai upaya penyelesaian problematika Pembelajaran di masa pandemi Covid-19 di sekolah dasar. Objek penelitian ini adalah siswa SD kelas 2 pada SDN Sidamukti Pangalengan Bandung. Metode yang digunakan adalah metode deskriptif. Pengumpulan data di lakukan dengan teknik observasi dan wawancara. wawancara terfokus kepada guru kelas karena beliau yang mengetahui secara persis permasalahan yang tengah di hadapi dalam pelaksanaan Pembelajaran di masa pandemi Covid-19. Data yang didapat diolah dengan cara di kelompokan, lalu di analisis dan terakhir di tarik kesimpulan (J. Moleong, 2005).

\section{Hasil Penelitian dan Pembahasan}

1. Problematika Pembelajaran di Masa Pandemi Covid-19

Meskipun Pembelajaran daring telah berjalan selama 2 semester terakhir, akan tetapi penerapannya masih belum optimal serta masih menghadapi berbagai macam permasalahan. berdasarkan hasil wawancara dengan guru permasalahan tersebut bersumber dari berbagai aspek mulai permasalahan yang di hadapi oleh 
guru itu sendiri, permasalahan yang dihadapi oleh siswa, serta permasalahan yang dihadapi orang tua atau wali siswa. Secara terperinci permasalahan yang berhasil di identifikasi berdasarkan hasil wawancara dan observasi di deskripsikan di bawah ini.

Pertama permasalahan yang dihadapi guru. berdasarkan hasil wawancara

permasalahan

Pembelajaran daring yang di hadapi oleh guru terletak pada pengelolaan kelas. Permasalahan pengelolaan kelas meliputi: sulitnya pembimbingan dan pengawasan pembelajaran, sulitnya menanamkan pendidikan karakter siswa, sulitnya menilai secara objektif.

Guru menjelaskan bahwa Pembelajaran daring di daerah pedesaan seperti ini tidak akan se optimal di Desa. Sebagai contoh saja di awal-awal dilaksanakannya Pembelajaran daring kami mencoba diskusi pada WA Grup dan yang terjadi kami mengalami kesulitan untuk berdiskusi dengan orang tua karena kurangnya pemahaman dan SDM Orang tua. Selain itu ada juga orang tua yang malah acuh tak acuh terhadap instruksi yang berikan untuk anak-anaknya bahkan. ada yang seenaknya mengumpulkan tugas misalnya batas pengumpulan jam 18:00 ini mengumpulkan jam 23:00 sehingga itu mengganggu waktu istirahat. Atau contoh lain pada saat video converence. Pada awal-awal pelaksanaan Pembelajaran daring banyak dari mereka yang kesulitan untuk mengoperasikan aplikasinya. Banyak yang tidak mengerti, sehingga alih-alih agar pembelajaran bisa dilakukan secara tatap muka meskipun melalui video converence malah waktu menjadi tidak efektif dan pembelajaran pun tidak berjalan lancar.

Penulis memandang bahwa permasalahan tersebut dikarenakan kurangnya kesiapan belajar daring baik siswa, orang tua, ataupun guru. kesiapan belajar akan mempengaruhi keberhasilan belajar (Mulyani, 2013). Oleh karena itu perlu kesiapan yang lebih optimal baik dari guru, siswa ataupun orang tua karena itu berpengaruh terhadap motivasi belajar siswa (Rizki, 2013)

Permasalahan lain yang dihadapi oleh guru dalam pelaksanaan pembelajaran adalah sulitnya menanamkan karakter dan menanamkan nilai sosial secara langsung. Berdasarkan analisis 
penulis Meskipun penanaman karakter dan sikap bisa di integrasikan dalam materi pembelajaran akan tetapi siswa membutuhkan role model yang membantu memberikan referensi cara bersikap, bertindak dan berperilaku. Dalam pembelajaran konvensional, seorang guru berperan membentuk dan menanamkan nilai karakter siswa (Sutisna, Indraswati, \& Sobri, 2019). Untuk sebagian siswa Terkadang peran guru bisa lebih besar di bandingkan orang tua dalam pembentukan karakter yang baik.

Dengan pembelajaran secara langsung seorang siswa dapat merasakan perhatian, kasih sayang, dan perlakuan yang di berikan oleh seorang guru sehingga siswa akan mengidentifikasikan dirinya sesuai dengan pengalaman dan perlakuan yang di dapatkan dari gurunya (Sobri, Widodo, \& Sutisna, 2019). Di situlah peran guru sebagai role model bagi siswa-siswanya sangat diperlukan.

Lain halnya jika pembelajaran daring. menurut hasil wawancara, intensitas interaksi antara guru dan siswa sangat terbatas. Bahkan komunikasi dan interaksi lebih banyak dengan orang tua. oleh karena itu kesempatan guru untuk mejadi role model bagi siswa-siswa nya sangat terbatas bahkan hilang.

Sebagai motor penggerak pendidikan guru berperan untuk mengantarkan peserta didik ke tahap lebih tinggi dari kedudukannya. Bukan hanya transfer ilmu, akan tetapi bagaimana caranya guru mampu menjadi teladan dengan menanamkan nilai-nilai kebaikan sehingga siswa memiliki kecakapan sosial dan emosional serta spiritual (Widodo, Indraswati, \& Sobri, 2019). Terlepas dari metode pembelajaran baik jarak jauh ataupun secara luring tugas guru tetap harus seperti itu meskipun pada implementasinya dianggap sulit.

Yang terakhir, kendala yang dihadapi oleh guru pada tahap penilaian. Tidak jarang tugas-tugas yang dikumpulkan bukan hasil kerja siswa tetapi bisa saja dikerjakan oleh kakak atau ayah ibunya. Sebagai contoh tugas menulis. Guru mencoba membandingkan tulisan siswa dengan tugas yang dikumpulkan. Dari sana terlihat jika tugas yang dikumpulkan lebih bagus dan lebih rapai. Setelah di tanya-tanya siswanya pada saat pertemuan tatap muka secara kelompok siswa membenarkan jika tugasnya dikerjakan oleh orang lain. 
Pengelolaan kelas merupakan upaya mengelola dan mengondisikan siswa di dalam kelas yang di tujukan untuk menciptakan suasana belajar yang kondusif sehingga mampu mencapai tujuan pembelajaran yang direncanakan (Efendi \& Gustrinasi, 2020). Oleh karena itu manajemen kelas merupakan kewenangan guru untuk menentukan arah pembelajaran agar lebih menyenangkan. Dengan pengelolaan yang baik dan tepat pembelajaran akan berjalan dengan efektif sehingga tujuan pembelajaran akan tercapai (Suryana, 2018).

Yang ke-dua adalah permasalahan yang dihadapi siswa. Berdasarkan wawancara, kendalakendala yang dihadapi oleh siswa dalam pelaksanaan Pembelajaran daring meliputi; kurang nya dukungan orang tua, kurangnya kemandirian belajar siswa dan kurangnya fasilitas dan media belajar. Guru mengungkapkan bahwa lokasi sekolah di pedesaan seperti ini pembelajaran online tidak akan seperti dilaksanakan di kota. Belum lagi jika orang tuanya kurang mendukung dan kurang memperhatikan anaknya.

Banyak kejadian diantara siswa yang tidak mengerjakan tugas yang telah diberikan dengan alasan tidak mengerti. Padahal tugas tersebut dijelaskan terlebih dahulu dan di Instruksikan kepada Orang tua siswa. Oleh karena itu orang tua memegang peranan penting dalam pelaksanaan Pembelajaran di masa pandemi Covid-19 dan bisa menjadi salah satu penentu keberhasilan Pembelajaran daring khususnya pada kelas rendah.

Guru mengatakan bahwa siswa kelas rendah dalam hal ini kelas 2 SD belum memiliki kemandirian belajar. Banyak diantara mereka yang belum bisa membaca dan menulis. Terlebih lagi kepercayaan diri mereka masih kurang. Tidak seperti anak di daerah perkotaan yang lebih cakap dan lebih percaya diri. Pernah pada suatu saat melakukan video converence siswa malah terus menunduk malu. Ada juga yang malah nangis, ada juga yang malah senyum-senyum terus. Hal-hal tersebut adalah permasalahanpermasalahan yang kerap dihadapi dalam Pembelajaran daring. berkaitan dengan hal tersebut peran orang tua mutlak diperlukan untuk menciptakan pembelajaran yang efektif.

Berdasarkan analisis peneliti, permasalahan tersebut berdasar atas sikap dan keinginan orang tua serta harapan untuk anak-anaknya. Pada 
Pembelajaran daring orang tua berperan sebagai pengganti guru dalam mengawasi, meninjau, dan membimbing siswa pada proses pembelajaran. Hal tersebut merupakan bentuk dukungan dan motivasi (Lilawati, 2021).

Orang tua dapat menjadi faktor eksternal penentu keberhasilan anak. Umar, (2015) menjelaskan ada tiga peran orang tua dalam pembelajaran; diantaranya sebagai penyedia informasi, penyedia kesempatan untuk siswa agar menemukan bakat, minat dan cita-cita, dan sebagai penyedia fasilitas serta sarana belajar di rumah.

Tanpa dukungan orang tua siswa tidak akan dapat mengikuti pembelajaran secara optimal, oleh karena itu perlu komitmen dan citacita orang tua untuk mengantarkan anaknya. Komitmen tersebut diperlukan agar orang tua mampu memberikan dukungan yang maksimal serta mampu membantu dan memfasilitasi anak-anaknya dalam Pembelajaran daring.

Ke tiga adalah Permasalahan yang dihadapi orang tua siswa. Orang tua menjadi sosok yang penting dalam menentukan keberhasilan Pembelajaran daring terutama pada kelas bawah seperti hal nya kelas 2 SD seperti ini. oleh karena itu orang tua mau tidak mau harus berperan aktif dalam pembelajaran agar hasilnya bisa lebih optimal (Hayati, 2020) . Berdasarkan wawancara, Ada beberapa kesulitan bagi orang tua dalam membantu anaknya dalam pelaksanaan Pembelajaran daring. kesulitan tersebut diantaranya: keterbatasan waktu, keterbatasan ekonomi, keterbatasan wawasan, dan buruknya pola asuh dan pola didik terhadap anak. Nara sumber menjelaskan sering terjadi siswanya tidak dapat mengirimkan tugas atau terlambat yang disebabkan tidak ada yang membimbing belajar.

Mereka orang tua beralasan karena mereka bekerja sehingga sulit untuk mengatur waktu antara pekerjaan dan membimbing anak belajar jarak jauh. padahal guru telah memberikan waktu yang lebih fleksibel. Jika dalam pembelajaran konvensional sudah jelas waktu belajarnya, sementara penugasan bisa di kerjakan kapan saja. Tetapi tetap saja masih banyak diantara siswa yang telat untuk menyelesaikan tugas-tugas yang diberikan oleh guru.

Pembimbingan orang tua mutlak di perlukan khususnya untuk 
kelas bawah di Sekolah dasar. Hasil penelitian dari Hayati, (2020) menjelaskan bawah siswa yang ditemani belajarnya lebih dominan memiliki sikap yang baik dan terbuka dibandingkan dengan siswa yang dibiarkan belajar sendiri. Hal tersebut sesuai dengan pendapat dari Cahyati \& Kusumah, (2020) yang menyatakan bahwa akan terjadi hubungan kelekatan yang baik antara anak dan orang tua manakala orang tua bisa selalu menemani anaknya belajar.

Selain kendala waktu, keterbatasan ekonomi keluarga menjadi faktor penyebab permasalahan pelaksanaan Pembelajaran daring. berdasarkan hasil wawancara menemukan fakta bahwa dari 36 siswa kelas 2 hanya 70 $\%$ atau 25 siswa yang orang tuanya yang memiliki handphon. Dari 25 orang tersebut hanya $25 \%$ yang selalu aktif dalam Pembelajaran daring. selebihnya dari itu berbagai alasan muncul. Tidak punya HP, tidak punya Kuota, HP nya di bawa bapak bekerja dan yang lainnya menjadi alasan para siswa.

sebagaimana kita ketahui bahwa Pembelajaran daring memerlukan media pembelajaran diantaranya laptop ataupun telepon pintar. Selain itu memerlukan kuota internet juga. Oleh karena itu untuk sebagian besar orang tua hal terebut menjadi sebuah beban. Informasi dari narasumber mengatakan bahwa mayoritas orang tua siswa berlatar belakang dari kalangan menengah ke bawah, bahkan sebetulnya hanya sebagian kecil dari mereka yang berasal dari kalangan menengah. Profesi orang tua mereka sebagian besar adalah seorang buruh, kerja serabutan, tukang ojek, pedagang kecil dan yang sejenisnya tidak memberikan banyak kekuatan untuk memberikan semua fasilitas belajar jarak jauh.

Pemerintah sebetulnya telah memberikan berbagai bantuan langsung baik kepada masyarakat miskin ataupun kepada pekerja. Selain itu juga melalui kementerian pendidikan dan kebudayaan pemerintah juga memberikan bantuan pulsa belajar. Meski demikian bantuan-bantuan tersebut belum sepenuhnya diterima oleh masyarakat secara merata. Berdasarkan informasi dari guru, untuk bantuan pulsa dari KEMENDIKBUD, belum semua siswa mendapatkan bantuan tersebut. Ada yang sudah beberapa kali dapat, tetapi ada yang sama sekali belum 
pernah mendapatkan. Sehingga tidak semua siswa dapat merasakan bantuan tersebut.

Tidak kalah penting dengan permasalahan diatas, pola asuh dan pola didik orang tua juga bisa menjadi faktor permasalahan keberhasilan Pembelajaran di masa pandemi Covid-19. tidak sedikit dari mereka yang mengalami kesulitan dalam mendidik anaknya, sehingga sulit dalam membimbing anaknya untuk belajar. Guru menjelaskan mereka lebih takut dengan gurunya dibandingkan dengan orang tua mereka sendiri, bahkan sering mendapatkan keluhan jika anaknya tidak mau nurut, sehingga harus menakut-nakuti dengan mencatut nama guru bersangkutan. Hal tersebut dilematis memang, tugas orang tua yang harusnya mampu membimbing, mendidik, dan mengajarkan nilai-nilai kehidupan tetapi sebagian dari orang tua tidak mampu memberikan semua itu. Dengan kondisi demikian maka orang tua tidak akan memiliki banyak kesempatan untuk dapat mendidik dan mengarahkan serta susah untuk memberikan hal-hal yang positif (Wulandari \& Kristiawan, 2017). Akan ada kecenderungan seorang anak yang tidak akan mendengarkan kata- kata orang tuanya. Maka dari itu orang tua akan kesulitan dalam mengarahkan dan membentuk karakter siswa (Anisah, 1997).

Masalah terakhir berkaitan dengan teknis. Berdasarkan hasil wawancara selain faktor manusia faktor teknis juga menjadi kendala dalam pelaksanaan Pembelajaran di masa pandemi Covid-19. ini kaitannya dengan koneksi jaringan internet yang tidak merata. Guru menjelaskan bahwa tidak semua siswa berada pada jangkauan jaringan yang bagus sehingga pelaksanaan Pembelajaran di masa pandemi Covid-19 tidak pernah maksimal dihadiri oleh seluruh siswa. Berdasarkan hasil observasi menunjukkan bahwa topografi daerah penelitian yang merupakan daerah perbukitan secara otomatis rumahrumah siswa tersebar di daerah tersebut. Selain itu perbedaan operator telepon celuller dengan perbedaan kapasitas jaringan dan tidak semua operator telepon celuller bisa digunakan di rumah siswa. Sehingga kendala-kendala jaringan lemah, tidak ada jaringan menjadi hal yang lumrah terjadi pada siswa. 


\section{Bentuk manajemen kelas daring} yang telah dilaksanakan Guru

Berdasarkan wawancara bentuk pengelolaan kelas yang telah dilakukan oleh guru dalam pembelajaran di masa pandemi Covic19 meliputi perencanaan pembelajaran, pelaksanaan pembelajaran, dan evaluasi pembelajaran. Untuk lebih jelasnya hasil penelitian di bahas pada paragraf di bawah ini.

Seperti halnya pembelajaran luring atau pembelajaran konvensional perencanaan Pembelajaran di masa pandemi Covid-19 memerlukan lebih persiapan. Meskipun pada dasarnya sama, akan tetapi perlu adanya penyesuaian baru mengingat Pembelajaran di masa pandemi Covid-19 juga tergolong baru. Berdasarkan hasil wawancara persiapan pembelajaran meliputi: penyesuaian perangkat pembelajaran (silabus, RPP, rancangan evaluasi pembelajaran dII).

Adapun komponen RPP yang di sesuaikan meliputi kegiatan awal, kegiatan inti dan kegiatan penutup. Pada kegiatan awal penyesuaian tidak terlalu signifikan. Kegiatan awal meliputi apersepsi. Hal tersebut sama halnya dengan Pembelajaran di masa pandemi Covid-19. yang membedakan hanya teknisnya saja antara tatap muka langsung dengan jarak jauh.

Meskipun

persiapan pembelajaran telah di susun sedemikian rupa, akan tetapi teknis penerapannya tidak seperti yang direncanakan.

Berbagai permasalahan yang kompleks seperti yang telah di bahas pada paragraf sebelumnya memaksa guru untuk berpikir lebih kreatif agar pembelajaran bisa lebih berjalan lebih efektif. Berdasarkan hasil wawancara guru tidak bisa menjalankan Pembelajaran daring baik dengan diskusi WA grup apalagi dengan video converence. Ada yang beralasan tidak memiliki kuota internet dan bahkan ada yang tidak bisa-bisa mengoperasikan aplikasi video converence. Hal terebut menyebabkan pembelajaran menjadi kacau, tidak terarah, dan tidak sesuai dengan tujuan pembelajaran. Atas dasar itu guru berpikir keras untuk mengganti metode pembelajaran. Lebih lanjut nara sumber mengatakan metode yang digunakan.

Berbagai cara yang telah dilakukan oleh guru untuk 
menyelesaikan

problematika

Pembelajaran di masa pandemi

Covid-19. nara sumber menjelaskan selama Pembelajaran di masa pandemi Covid-19 beliau telah mencoba berbagai cara agar pembelajaran bisa lebih efektif.

Teknik yang telah di coba meliputi: 1). Memberikan bimbingan pembelajaran secara personal kepada setiap siswa baik dengan panggilan telepon ataupun dengan video call contohnya untuk mengajarkan membaca ataupun menulis dan yang lainnya. Hal tersebut masih kurang efektif mengingat jumlah siswa yang berjumlah 36 orang sehingga dalam satu minggu mereka hanya berkesempatan $1 \mathrm{X}$ pembimbingan personal;

Ke 2) memberikan bimbingan secara berkelompok dengan jumlah anggota 5 orang setiap kelompoknya. Teknisnya guru berkunjung ke rumah salah seorang siswa dan semua anggota kelompok berkumpul. Kendala yang ditemukan dalam teknik guru kunjung ini meliputi kurangnya dukungan orang tua sehingga terkadang siswa seenaknya datang, kondisi rumah siswa yang terkadang tidak memadai untuk dilaksanakannya pembelajaran (tempat tidak representatif, terlalu berisi, dII); waktu pelaksanaan terbatas karena dalam sehari guru hanya mampu membimbing satu kelompok dengan durasi belajar 2-3 jam, oleh karena itu dalam satu minggu siswa hanya mendapatkan kesempatan mendapatkan bimbingan kelompok 1 $\mathrm{X}$ pertemuan;

$\mathrm{Ke}$ 3) adalah dengan siswa yang mengunjungi guru. Pada dasarnya ini hampir sama dengan yang ke dua, akan tetapi yang membedakan adalah siswa yang berkunjung. Dengan cara ini intensitas pertemuan bisa lebih sering. Teknisnya siswa diberikan ter untuk mengetahui kemampuan belajar, itu kelompokkan berdasarkan kemampuan agar memudahkan dalam pembimbingan, setelah itu diberikan jadwal pertemuan tatap muka di tempat yang telah di sepakati (di rumah guru atau di tempat dekat rumah guru). Dengan metode ini guru tidak terlalu menghabiskan waktu di jalan untuk bertemu siswa sehingga dalam satu hari guru bisa membimbing 2 kelompok dalam waktu yang berbeda. Cara ini lebih efektif karena setiap kelompok bisa di bimbing secara langsung oleh guru sebanyak $2 X$ pertemuan. 
Selain teknik diatas guru juga memberikan modul belajar yang telah di siapkan sebelumnya. Modul tersebut berbentuk rubrik kegiatan harian dan penugasan sehingga setiap harinya siswa menyelesaikan tugas yang telah di siapkan guru dalam modul tersebut. Komunikasi dengan orang tua tetap menjadi prioritas karena mereka yang bertugas menggantikan guru dalam membimbing, mengarahkan, dan menginstruksikan pembelajaran kepada anak-anaknya.

\section{Evaluasi belajar}

Tahap evaluasi dilakukan dengan memeriksa tugas-tugas yang telah di kumpulkan oleh siswa. Jika awalnya orang tua yang mengumpulkan dan mengambil tugas, sekarang dengan ditambahnya metode pembimbingan kelompok membuka kesempatan guru dalam mengevaluasi dan mengarahkan siswa meskipun dalam waktu yang terbatas.

Upaya yang telah dilakukan guru merupakan sebuah usaha agar pembelajaran tetap berjalan optimal meskipun dalam keterbatasan. Somantri, (2014) menyebutkan bahwa guru memiliki peran utama dalam manajemen kelas. Lebih lanjut (Sari \& Hadijah, 2017) manajemen kelas yang baik akan menghasilkan kualitas belajar yang baik. Oleh karena itu guru SDN Sidamuki selalu berupaya untuk meningkatkan kualitas belajar siswa. Kualitas belajar akan tercapai mana kala guru mampu menerapkan manajemen kelas yang tepat (Erwinsyah, 2017). Kemampuan inilah yang terus dikembangkan agar pembelajaran berjalan efektif (Hendriati, 2017).

Berdasarkan hasil penelitian, model manajemen kelas pada Pembelajaran di masa pandemi Covid-19 yang telah di lakukan oleh guru kelas 2 SDN Sidamukti digambarkan seperti bagan di bawah ini. 




Gambar 1 Model Manajemen Kelas Pembelajaran di masa pandemi Covid-19

\section{E. Kesimpulan}

Berdasarkan hasil penelitian dapat disimpulkan bahwa problematika Pembelajaran di masa pandemi Covid-19 yang terjadi meliputi 3 dimensi. Ke tiga dimensi tersebut meliputi: 1). Permasalahan yang dihadapi oleh guru diantaranya: sulitnya pembimbingan dan pengawasan pembelajaran, sulitnya menanamkan pendidikan karakter siswa, sulitnya menilai secara objektif; 2). Permasalahan yang di hadapi siswa, yang meliputi kurang nya dukungan orang tua, kurangnya kemandirian belajar siswa dan kurangnya fasilitas dan media belajar; 3). Permasalahan yang dihadapi oleh 
Orang tua siswa. Yang meliputi: keterbatasan waktu, keterbatasan ekonomi, keterbatasan wawasan, dan buruknya pola asuh dan pola didik terhadap anak.

Selain itu usaha guru dalam memaksimalkan manajemen kelas dalam Pembelajaran di masa pandemi Covid-19 sebagai upaya agar pembelajaran bisa berjalan lebih efektif meliputi tiga tahapan diantaranya;1). Tahap persiapan dengan menyesuaikan perangkat pembelajaran dari pembelajaran luring ke pembelajaran daring. penyesuaian terutama pada rencana program pembelajaran (RPP); 2) tahap pelaksanaan. Teknis pembelajaran yang di lakukan oleh guru meliputi bimbingan personal melalui daring, membentuk kelompok siswa berdasarkan kemampuan siswa, melakukan kunjungan kepada kelompok kecil yang telah dibentuk sebelumnya, kelompok kecil siswa yang mengunjungi guru, memberikan modul dan penugasan yang dikumpulkan dan di evaluasi setiap satu minggu sekali. dengan model manajemen seperti ini Pembelajaran di masa pandemi Covid-19 lebih efektif dibandingkan pembelajaran online yang telah di laksanakan sebelumnya.

Sebagaimana kita ketahui Pembelajaran di masa pandemi Covid-19 masih banyak menemukan kendala oleh karena itu diperlukan penelitian lebih dalam terkait solusi pemecahan masalah Pembelajaran di masa pandemi Covid-19. Saran lain untuk penelitian selanjutnya adalah model pembelajaran yang telah diracang berdasarkan yang telah di laksanakan di siswa kelas 2 SDN Sidamukti masih perlu dikembangkan agar bisa memberikan manfaat lebih luas bagi yang lain.

\section{DAFTAR PUSTAKA}

Anisah, A. S. (1997). Pola asuh orang tua dan implikasinya terhadap pembentukan karakter anak. 7084.

Anugrahana, A. (2020). Hambatan, Solusi dan Harapan:

Pembelajaran Daring Selama Masa Pandemi Covid-19 Oleh Guru Sekolah Dasar. Jurnal Scholaria, 10(3), 282-289. https://doi.org/https://doi.org/10.2 4246/j.js.2020.v10.i3.p282-289

Cahyati, N., \& Kusumah, R. (2020). Peran Orang Tua Dalam Menerapkan Pembelajaran Di Rumah Saat Pandemi Covid 19. 04(1), 4-6.

Efendi, R., \& Gustrinasi, D. (2020). Manajemen Kelas DI Sekolah Dasar. Pasuruan: Qiara Medika.

Erwinsyah, A. (2017). Manajemen kelas dalam meningkatkan 
efektifitas proses belajar mengajar. 5.

Hayati, A. S. (2020). Peran Orang

Tua dalam Meningkatkan Motivasi Belajar Anak Dengan Sistem Daring pada Masa Pandemi di Desa Depokrejo , Kebumen Arifia Sabila Hayati. 2, 23-32.

Hendriati, A. (2017). KEMAMPUAN MANAJEMEN KELAS GURU : PENELITIAN TINDAKAN DI SEKOLAH DASAR DENGAN SES RENDAH. 16(2), 89-104.

J. Moleong, L. (2005). Metode Penelitian Kualitatif. Bandung: PT Remaja Rosdakarya.

Kawuryan, S. P. (1992).

KARAKTERISTIK SISWA SD KELAS RENDAH DAN PEMBELAJARANNYA. Diambil dari

http://staffnew.uny.ac.id/staff/132 313274

Lilawati, A. (2021). Peran Orang Tua dalam Mendampingi Anak di Masa Pandemi Covid-19. Jurnal Pendidikan Anak Usia Dini, 5(1), 241-256.

https://doi.org/10.31004/obsesi.v $5 \mathrm{i} 1.541$

Mulyani, D. (2013). HUBUNGAN KESIAPAN BELAJAR SISWA DENGAN PRESTASI BELAJAR Abstract Readiness to learn is the most important factor in determining student success in learning . In fact encountered many students have not the readiness to learn like this out in the study , li. 2(1), 27-31.

Diambil dari

http://ejournal.unp.ac.id/index.ph p/konselor\%0AHalaman

Mustaqbal, M. S., Firdaus, R. F., \& Rahmadi, H. (2015).

PENGUJIAN APLIKASI MENGGUNAKAN BLACK BOX TESTING BOUNDARY VALUE
ANALYSIS (Studi Kasus:

Aplikasi Prediksi Kelulusan

SNMPTN). I(3), 31-36.

https://doi.org/https://doi.org/10.3

3197/jitter.vol1.iss3.2015.62

Rahmawati, N. R., Rosida, F. E., \&

Kholidin, F. I. (2020). Analisis

Pembelajaran Daring Saat

Pandemi Di Madrasah Ibtidaiyah.

SITTAH: Journal of Primary

Education, 1(2), 139-148.

https://doi.org/10.30762/sittah.v1i 2.2487

Rigianti, H. A. (2020). KENDALA

PEMBELAJARAN DARING GURU SEKOLAH DASAR DI KABUPATEN BANJARNEGARA.

7(September), 92027.

https://doi.org/https://doi.org/10.3 1316/esjurnal.v7i2.768

Rizki, U. Y. (2013). HUBUNGAN KESIAPAN BELAJAR DENGAN OPTIMISME MENGERJAKAN UJIAN. 2(1), 49-56. Diambil dari http://journal.unnes.ac.id/sju/inde x.php/epj\%0AHUBUNGAN

Roni Hamdani, A., \& Priatna, A. (2020). Efektifitas Implementasi Pembelajaran Daring (Full Online) Dimasa Pandemi Covid19 Pada Jenjang Sekolah Dasar Di Kabupaten Subang. Didaktik: Jurnal IImiah PGSD STKIP Subang, 6(1), 1-9. https://doi.org/10.36989/didaktik. v6i1.120

Rusyan, A. T., Winarni, W., \& Hermawan, A. (2020). Membangun Kelas Aktif dan Inspiratif. Sleman: Budi Utama.

Sari, B. P., \& Hadijah, H. S. (2017). Meningkatkan disiplin belajar siswa melalui manajemen kelas ( Improving students 'learning discipline through classroom management ). 2(2), 233-241.

Sobri, M., Widodo, A., \& Sutisna, D. (2019). Pembentukan karakter disiplin siswa melalui kultur 
sekolah. 6(1), 61-71.

Somantri, M. (2014). Perencanaan

Pendidikan (Vol. 1). Bogor: IPB

Press.

Suryana, A. (2018). Manajemen

Kelas.

Sutisna, D., Indraswati, D., \& Sobri, M. (2019). Keteladanan Guru sebagai Sarana Penerapan Pendidikan Karakter Siswa. (September), 29-33.

https://doi.org/http://dx.doi.org/10 .26737/jpdi.v4i2.1236

Umar, M. (2015). Peranan Orang Tua Dalam Peningkatan Prestasi

Belajar Anak. JURNAL

EDUKASI: Jurnal Bimbingan

Konseling, 1(1), 20.

https://doi.org/10.22373/je.v1i1.3 15

Waridah, E., \& Suzana. (2014).

Kamus Bahasa Indonesia.

Bandung: Kawah Media.

Widodo, A., Indraswati, D., \& Sobri, M. (2019). Analisis Nilai-Nilai Kecakapan Abad 21 Dalam Buku. Jurnal Tarbiyah: Jurnal IImiah Kependidikan, 8(2), 125133.

https://doi.org/10.18592/tarbiyah. v8i2.3231

Wulandari, Y., \& Kristiawan, M.

(2017). Strategi Sekolah Dalam Penguatan Pendidikan Karakter Bagi Siswa Dengan Memaksimalkan Peran Orang Tua. JMKSP Jurnal Manajemen, Kepemimpinan, dan Supervisi Pendidikan, 2(2), 290-303.

https://doi.org/http://dx.doi.org/10 .31851/jmksp.v2i2.1477 